\title{
Reflectance as a decision-making tool for the application of fungicide to the Asian Soybean Rust
}

\section{Reflectância como ferramenta de decisão para a aplicação de fungicida na ferrugem asiática da soja}

\author{
Roger N. Michels ${ }^{1 \star}$, Marcelo G. Canteri², Marcelo A. de Aguiar e Silva², Janksyn Bertozzi \\ and Tatiane C. Dal Bosco 4 \\ 1 Universidade Tecnológica Federal do Paraná - UTFPR, Departamento Acadêmico de Engenharia Mecânica, Londrina, Brasil \\ 2 Universidade Estadual de Londrina - UEL, Centro de Ciências Agrarias, Londrina, Brasil \\ 3 Universidade Tecnológica Federal do Paraná - UTFPR, Departamento Acadêmico de Química, Londrina, Brasil \\ 4 Universidade Tecnológica Federal do Paraná - UTFPR, Departamento Acadêmico de Engenharia Ambiental, Londrina, Brasil \\ (*E-mail: rogernmichels@utfpr.edu.br) \\ http://dx.doi.org/10.19084/RCA17333
}

Received/recebido: 2017.12 .20

Received in revised form/recebido em versão revista: 2018.04.17

Accepted/aceite: 2018.04 .17

\begin{abstract}
A B S T R A C T
The objective of this study was to evaluate the application of GreenSeeker ${ }^{\circledR}$ (radiometer) the ideal time of application of fungicide on soybeans and the relationship between NDVI (Normalized Difference Vegetation Index) and productivity. Two experiments were conducted at the Universidade Estadual de Londrina (2012/2013 and 2013/2014 crops), both with experimental design of random blocks (6x4). The treatments aimed at obtaining a disease gradient (Asian soybean rust) by means of different numbers and times of application of fungicide. The quantification of the severity of the disease was made through the diagram scale and the readings of NDVI. Were analyzed the total mass, the 1.000 grains mass, the humidity, and productivity in $\mathrm{kg} \mathrm{ha}^{-1}$. A decrease in productivity was observed in connection with the delay in the application of the fungicide and the same happened in the area below the NDVI curve. At the same time when a statistical difference between the treatments of the severity was observed there was also a significant statistical difference $(\mathrm{P}<0.05)$ between the values of NDVI. The NDVI contributes to decision making about the best moment for the application of fungicide in the culture of soy for the control of Asian rust and presents regular results for the estimation of productivity.
\end{abstract}

Keywords: NDVI, Phakopsora pachyrhizi, radiometer.

\section{R E S U M O}

O objetivo deste estudo foi avaliar a aplicação de GreenSeeker ${ }^{\circledR}$ (radiômetro) na detecção do momento ideal para a aplicação de fungicida na soja e a relação entre NDVI (Normalized Difference Vegetation Index) e produtividade. Dois experimentos foram realizados na Universidade Estadual de Londrina (culturas 2012/2013 e 2013/2014), ambos com delineamento experimental de blocos ao acaso (6x4). Os tratamentos visavam a obtenção de um gradiente de doença (ferrugem asiática da soja) por meio de diferentes números e épocas de aplicação de fungicida. A quantificação da severidade da doença foi feita por meio da escala diagramática e das leituras de NDVI. Foram analisadas a massa total, a massa de 1.000 grãos, a umidade e a produtividade em $\mathrm{kg} \mathrm{ha}^{-1}$. Observou-se uma queda na produtividade em relação ao atraso na aplicação do fungicida e o mesmo ocorreu na área abaixo da curva do NDVI. Ao mesmo tempo em que observou-se diferença estatística entre os tratamentos para a severidade da doença, houve diferença estatística significativa $(\mathrm{P}<0,05)$ entre os valores de NDVI. O NDVI contribuiu para a tomada de decisão sobre o melhor momento para a aplicação de fungicida na cultura da soja para o controle da ferrugem asiática e apresenta resultados regulares para a estimação da produtividade.

Palavras-chave: NDVI, Phakopsora pachyrhizi, radiômetro. 


\section{INTRODUCTION}

The Asian soybean rust [Glycine max (L.) Merr.] is caused by the fungus Phakopsora pachyrhizi Syd. \& p. Syd., from the Australasian region. For infection, the $p$. pachyrhizi urediniospores require a period of 6 to 24 hours of free water on the leaf and a temperature in the range between 15 and $25^{\circ} \mathrm{C}$ (Furtado et al., 2009).

The occurrence of Asian rust brings on early defoliation, reducing the photosynthesis of the plant and affecting, consequently, the number and mass of the seeds (Guan \& Nutter Jr, 2002; Gregorutti et al., 2012; Thompson et al., 2014). An option to reduce losses in productivity is the application of fungicides (Deb et al., 2010; Dorighello et al., 2015).

In average two to three applications of fungicide are carried out during the soy cycle, starting from the blossoming according to the calendar (Godoy et al., 2009; Martins \& Juliatti, 2014), but the unnecessary use of fungicide increases production costs and the risk of resistance beyond the negative environmental impact (Carmona et al., 2015). Excessive application of fungicide may also cause changes in the physic-chemical in the grains of soy (Michels et al., 2016).

Soy presents a high capacity to absorb light in comparison with other cultures, since it has a high index of foliar area. Thus, the monitoring of the area of the leaves is a strategy for the maintenance of the productive potential of cultures (Fioreze et al., 2011).

The behavior of the reflectance measurements and the percentage of sunlight reflected by the plant, in different cultivation situations, constitute relevant information to be used in the elaboration of models of damage estimation based on reflectance measurements (Hikishima et al., 2010), for productivity forecast (Ali et al., 2014), in precision agriculture for the application of fertilizers (Chang et al., 2014) and for early detection of lesions from herbicides in the culture of soy (Yao et al., 2012). It may also detect variations in the foliar area of diseased plants and serves as a parameter for the estimation of damages in production (Yao et al., 2013; Ali et al., 2014).

NDVI (Normalized Difference Vegetation Index) is a normalized vegetation index defined as: NDVI+RED-NIR/RED+NIR, where RED is the radiation in the red band $(650 \mathrm{~nm})$ falling on the vegetal surface and NIR is the proximate infra-red radiation $(770 \mathrm{~nm})$ reflected by it.

NDVI should be adopted as a portable system, able to produce precise and exact recommendations for data quantification and helpful for the decision making about the best moment for the application of defensives. For this objective it is necessary to adopt the control parcel, disease free, in order to obtain the difference in absorption if compared with the situation of production (Bergamin Filho et al., 1995). The radiometer would capture variations between diseased parcels and controlled parcels in a timely manner.

Accordingly, the objective of this paper was to evaluate the application of NDVI in the detection of the ideal moment for the application of fungicide in soy and the ratio between reflectance and the productivity of the culture.

\section{MATERIAL AND METHODS}

Reflectance readings, that is, the percentage of light reflected by the plant, were carried out weekly after the first application of the fungicide using the portable equipment GreenSeeker ${ }^{\circledR}$ model RT100, from NTech. Three reading per parcel were carried out with the equipment over the useful area of each parcel, at a distance of $0.50 \mathrm{~m}$ over the plant canopy. Readings were made in the morning, between 9:00 a.m. and 12:00 noon.

The tests were conducted at the Federal University of Londrina (UEL), located in the municipality of

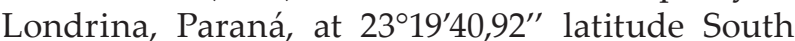
and $51^{\circ} 12^{\prime} 19,20^{\prime \prime}$ longitude West and $560 \mathrm{~m}$ altitude, on the occasion of the 2012/2013 crops (Test 1) and 2023/2014 (Test 2). Sowing was made on December 142012 for the 2012/2013 crop and on December 5 2013 for the 2013/2014 crop. The soy cultivations adopted were BMX Potência RR and M 6410 IPRO, respectively. Sowings were carried out at the final limit of the recommended period of time with the aim of ensuring a greater amount of inoculation of the fungus originating from the first sowings in the region (Godoy et al., 2009).

The experimental design of the tests was made in random blocks, with four repetitions, each one 
made up of parcels with five lines six meters long and $0.45 \mathrm{~m}$ of space between the lines. The three central lines and 4 linear meters were considered as the useful area for the application of the treatments and gathering of data. Two external lines and 1 meter of the extremities of the parcel were used as borders (Michels et al., 2015). The gradient of intensity of the rust was generated by means of the variation of application of the fungicide along the calendar (Table 1).

The treatments aimed at obtaining a gradient of disease (Asian soy rust) through different numbers and times of application of the fungicide. The fungicide used for the gradient of intensity of Asian soy rust was the commercial mixture of Pyraclostrobin + Epoxyconazol $\left(66.5+25\right.$ g i.a. ha ${ }^{-1}$, with a dose of 500 mL.ha- ${ }^{-1}$ for a volume of 200 L.ha $^{-1}$ with mineral oil as a vehicle, in the dose of $500 \mathrm{~mL} \cdot \mathrm{ha}^{-1}$.

Treatment T2 was established as control parcel with the intention of being the parcel free of the disease, needed in order to ascertain the moment in which a difference of NDVI with the other treatments occurs and serving as the parameter to estimate the best moment for the application of the fungicide.

The quantification of severity, defined as the percentage of the foliar area covered with symptoms of the disease was made through the diagram scale (Godoy et al., 2006). Evaluations started since the development of the first pustules and were made weekly until total defoliation. Two areas of $10 \mathrm{~m} \times 10 \mathrm{~m}$, with identical treatments, named Dest1 (witness) and Dest2 (control), respectively, conducted in parallel to the experiment, were devoted to destructive tests, unlike Hikishima et al.

Table 1 - Number and moment of pulverizations carried out in the respective treatments for the control of Asian soy rust ( $P$. pachyrhizi) in crops 2012/2013 (Experiment 1) and 2013/2014 (Experiment 2)

\begin{tabular}{ccc}
\hline Treatment & $\begin{array}{c}\text { Number } \\
\text { of pulverizations. }\end{array}$ & $\begin{array}{c}\text { Moment of the pulverization } \\
\text { (Days after germination) }\end{array}$ \\
\hline T1 & 0 & - \\
T2 & 6 & $30,45,60,75,90,105$ \\
T3 & 5 & $45,60,75,90,105$ \\
T4 & 4 & $60,75,90,105$ \\
T5 & 3 & $75,90,105$ \\
T6 & 2 & 90,105 \\
\hline
\end{tabular}

(2010), who quantified the severity of the disease in the parcels where the reflectance data were collected. Using the methodology of Hikishima et al. (2010), evaluations were carried out in 12 trefoils ( 4 of the lower third, 4 of the medium third and 4 of the upper third) per parcel.

The area under the NDVI progress curve was calculated by adapting the methodology proposed by Campbell \& Madden (1990). This adjustment was made due to the decision not to carry out the destructive disease severity test in the areas with the treatments.

After the harvest and threshing of the soy contained in the useful area of the parcels the total mass $(\mathrm{g})$, the 1.000 grains mass $(\mathrm{g})$ and the humidity (5) of the seeds were analyzed. Ten plants per parcel were also harvested for separate analysis of the height of the plant $(\mathrm{cm})$, the number of pods per plant and the number of grains per pod.

\section{RESULTS AND DISCUSSION}

Upon carrying out Pearson's correlation between the severity of the disease in the destructive are and the witness treatment (Dest1) and the average of NDVI obtained in the same area, the values of 96.9\% in Experiment 1 and 98.3\% in Experiment 2 were observed, and between the average of NDVI in the repetitions of the witness treatment (T1) the values of $96.9 \%$ in Experiment 1 and of $98.8 \%$ in Experiment 2 were observed. By carrying out the correlation between the severity of the disease in the destructive area with the control treatment (Dest2) and the average NDVI obtained in the same area, the values of $86 \%$ in Experiment 1 and of $97.7 \%$ in Experiment 2 were obtained, that is, there is a strong correlation between the severity of the disease Asian soy rust and NDVI, both in the readings made at the destructive area itself and in comparison with the treatments (Table 2). Upon performing linear regression, Hikishima et al. (2010) found R2 between $89 \%$ and $95 \%$ between the two parameters, values close to the ones presented in this paper.

Thus, the results of Table 2 express strong correlation between the severity of the disease and NDVI, as well as a correlation between evaluations in the destructive area and the parcels of the test. 
Table 2 - Pearson's correlation between the severity of the disease and NDVI between the treatments and the destructive area of Experiment 1 and 2

\begin{tabular}{cccc}
\hline $\begin{array}{c}\text { Severity of the } \\
\text { disease }\end{array}$ & NDVI & $\begin{array}{c}\text { Pearson's } \\
\text { correlation } \\
\text { Experiment 1 }\end{array}$ & $\begin{array}{c}\text { Pearson's } \\
\text { correlation } \\
\text { Experiment 2 }\end{array}$ \\
\hline Dest 1 & Dest 1 & $96,6 \%$ & $98,3 \%$ \\
Dest 1 & T1 & $96,6 \%$ & $98,8 \%$ \\
Dest 2 & Dest 2 & $86,0 \%$ & $97,7 \%$ \\
Dest 2 & T2 & $90,0 \%$ & $98,5 \%$ \\
\hline
\end{tabular}

The disease showed symptoms in the culture at the end of the cycle in both experiments, but in the 2012/2013 crop the severity was numerically greater and occurred earlier. In the 2013/2014 crop there was less progress of the Asian rust because there was no precipitation in sufficient amounts. The same occurrence was reported by Koga et al. (2007). The behavior of the evolution of the severity of the disease between the two destructive areas in Experiment 1 and 2 may be seen in Figure 1.

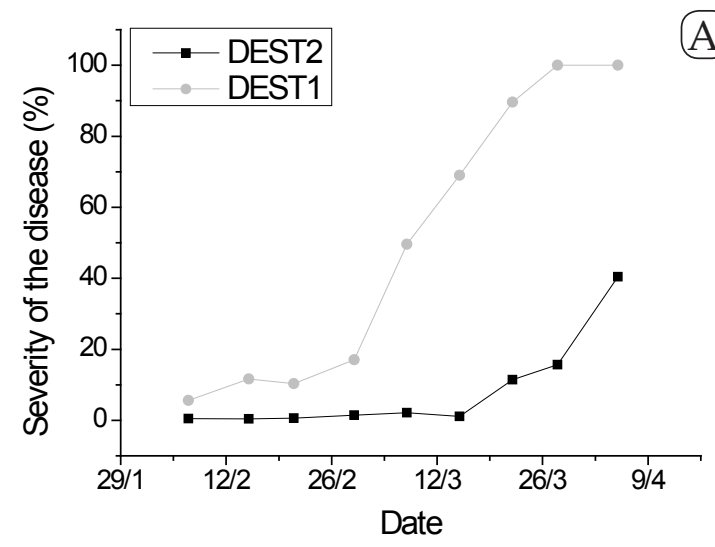

Upon making the comparison of the average using the Scott-Knott test at 5\% significance over time with the readings of the radiometer, a statistical difference was found in the data from 2 March 2013, 78 days after sowing (Table 3). Treatments T2, T3 and T4 were superior to Treatments T1, T5 and T6 in Experiment 1. Upon performing the T test for the data of severity of the Asian soy rust over time for the witness treatments (Dest1) and control (Dest2) a statistical difference is observed $(\mathrm{P}<0.05)$ from 2 March 2013 (Table 4), i.e., on the same date in which a statistical difference in NDVI was observed.

In Experiment 2, upon making the average comparison utilizing the Scott-Knott significance test over time with the readings of the radiometer, differences were observed from 5 February 2014, but these occurred due to spots on the soil. From 20 March 2014, 105 days after sowing, there was a statistical difference in NDVI due to the effects of the disease, treatments $\mathrm{T} 2, \mathrm{~T} 3, \mathrm{~T} 4$ and $\mathrm{T} 5$ being

Figure 1 - Evolution of the severity of the disease (\%) in destructive evaluations in the control and witness treatments over the time of Experiment $1(\mathrm{~A})$ and of Experiment 2 (B).

Table 3 - Normalized difference vegetation index (NDVI) for treatments with different gradients of Asian soy rust (T1, T2, T3, T4, T5 and T6) over the time of Experiment 1

\begin{tabular}{|c|c|c|c|c|c|c|c|c|c|}
\hline Trat. & $30 / 01$ & $16 / 02$ & $23 / 02$ & $02 / 03$ & $09 / 03$ & $16 / 03$ & $22 / 03$ & $01 / 04$ & $07 / 04$ \\
\hline $\mathrm{T} 1$ & $0,842 \mathrm{a}$ & $0,861 \mathrm{a}$ & $0,842 \mathrm{a}$ & $0,796 a$ & $0,737 a$ & $0,611 a$ & $0,372 a$ & $0,288 \mathrm{a}$ & $0,275 a$ \\
\hline $\mathrm{T} 2$ & $0,847 a$ & $0,858 \mathrm{a}$ & $0,832 \mathrm{a}$ & $0,823 b$ & $0,809 b$ & $0,788 \mathrm{c}$ & $0,678 c$ & $0,319 a$ & $0,279 a$ \\
\hline T3 & $0,862 \mathrm{a}$ & $0,860 \mathrm{a}$ & $0,838 \mathrm{a}$ & $0,819 b$ & $0,805 b$ & $0,789 c$ & $0,665 c$ & $0,380 b$ & $0,313 a$ \\
\hline $\mathrm{T} 4$ & $0,854 \mathrm{a}$ & $0,862 a$ & $0,835 a$ & $0,810 \mathrm{~b}$ & $0,785 b$ & $0,750 \mathrm{c}$ & $0,639 c$ & $0,346 b$ & $0,311 a$ \\
\hline T5 & $0,859 a$ & $0,860 \mathrm{a}$ & $0,832 \mathrm{a}$ & $0,793 a$ & $0,748 a$ & $0,664 b$ & $0,480 b$ & $0,354 b$ & $0,304 a$ \\
\hline T6 & $0,854 \mathrm{a}$ & $0,863 a$ & $0,832 \mathrm{a}$ & $0,795 a$ & $0,733 a$ & $0,582 \mathrm{a}$ & $0,364 \mathrm{a}$ & $0,275 a$ & $0,262 \mathrm{a}$ \\
\hline
\end{tabular}

*Similar letters in the column indicate statistical equality at $5 \%$ of significance $(P<0.05)$. 
Table 4 - Severity of the Asian soy rust for witness (Dest1) and control (Dest 2) treatments over the time of Experiment 1

\begin{tabular}{cccccccccc}
\hline Treat. & $\mathbf{3 0 / 0 1}$ & $\mathbf{1 6 / 0 2}$ & $\mathbf{2 3 / 0 2}$ & $\mathbf{0 2 / 0 3}$ & $\mathbf{0 9 / 0 3}$ & $\mathbf{1 6 / 0 3}$ & $\mathbf{2 2 / 0 3}$ & $\mathbf{0 1 / 0 4}$ & $\mathbf{0 7 / 0 4}$ \\
\hline Dest2 & $0,458 \mathrm{a}$ & $0,375 \mathrm{a}$ & $0,591 \mathrm{a}$ & $1,450 \mathrm{a}$ & $2,141 \mathrm{a}$ & $\mathbf{1 , 1 0 0 \mathrm { a }}$ & $11,42 \mathrm{a}$ & $15,65 \mathrm{a}$ & $40,41 \mathrm{a}$ \\
Dest1 & $5,608 \mathrm{a}$ & $3,033 \mathrm{a}$ & $\mathbf{1 0 , 3 5 \mathrm { a }}$ & $\mathbf{1 7 , 0 8 \mathrm { b }}$ & $\mathbf{4 9 , 5 8 \mathrm { b }}$ & $\mathbf{6 9 , 0 0 \mathrm { b }}$ & $\mathbf{8 9 , 6 8 \mathrm { b }}$ & $\mathbf{1 0 0 , 0 \mathrm { b }}$ & $\mathbf{1 0 0 , 0 \mathrm { a }}$ \\
\hline
\end{tabular}

* Similar letters in the column indicate statistical equality at $5 \%$ of significance $(P<0.05)$.

superior to Treatments T1 and T6 (Table 5). Upon performing Test $\mathrm{T}$ for the severity data of the Asian soy rust over time for the witness treatments (Dest1) and control (Dest2), a statistical difference $(P<0.05)$ was observed from March 172013 (Table 4), that is, three days before the detection of the statistical difference in NDVI.

Isolating treatments $\mathrm{T} 1$ and $\mathrm{T} 2$ (witness and control respectively) and applying Test $\mathrm{T}$ with $5 \%$ significance, statistical difference was found on the same date of the Scott-Knott test for Experiment 1. In Experiment 2 the difference occurred on 17 March 2014, that is, 102 days after sowing, the same date of the statistical difference found in Test $\mathrm{T}$ of the severity of Asian soy rust. In this way, it is noted that the disease diminishes the healthy foliar coverage of the culture, influencing the value of NDVI. Hikishima et al. (2010) observed the same effect in their study. The behavior of NDVI between the treatments of the experiment can be seen in Figure 2.
By calculating the area below the NDVI progress curve (AACPNDVI) it is possible to verify that the number of sprays influences NDVI maintenance, that is, the higher incidence of Asian rust decreases the leaf cover and, consequently, decreases the NDVI. It can be observed in Figure 3 where the linear progression points to the tendency of increase of AACPNDVI with the number of sprays in both Experiment 1 and Experiment 2. In Experiment 2 the progression is less intense due to the lower incidence of the disease compared to Experiment 1. It can be verified in Table 7 the AACPNDVI mean comparison for treatments, at $5 \%$ of significance, and it is noted that there is no statistical difference in Experiment 2, but in Experiment 1, there is difference between the treatments with the highest number of fungicide application (T2, T3 and T4) and lower number of fungicide application (T1, T5 and T6).

Table 5 - Normalized difference vegetation index (NDVI) in treatments with different gradients of Asian soy rust (T1, T2, T3e, T, T5 and T6) over the time of Experiment 2

\begin{tabular}{ccccccccccccc}
\hline Treat & $\mathbf{1 2 / 0 1}$ & $\mathbf{2 2 / 0 1}$ & $\mathbf{3 0 / 0 1}$ & $\mathbf{0 5 / 0 2}$ & $\mathbf{1 2 / 0 2}$ & $\mathbf{1 9 / 0 2}$ & $\mathbf{2 6 / 0 2}$ & $\mathbf{0 6 / 0 3}$ & $\mathbf{1 7 / 0 3}$ & $\mathbf{2 0 / 0 3}$ & $\mathbf{2 6 / 0 3}$ & $\mathbf{0 2 / 0 4}$ \\
\hline t1 & $0,706 \mathrm{a}$ & $0,817 \mathrm{a}$ & $0,834 \mathrm{a}$ & $0,792 \mathrm{~b}$ & $0,829 \mathrm{a}$ & $0,803 \mathrm{~b}$ & $0,820 \mathrm{a}$ & $0,803 \mathrm{a}$ & $0,775 \mathrm{a}$ & $0,760 \mathrm{a}$ & $0,386 \mathrm{a}$ & $0,262 \mathrm{a}$ \\
t2 & $0,685 \mathrm{a}$ & $0,802 \mathrm{a}$ & $0,820 \mathrm{a}$ & $0,765 \mathrm{a}$ & $0,802 \mathrm{a}$ & $0,789 \mathrm{a}$ & $0,815 \mathrm{a}$ & $0,800 \mathrm{a}$ & $0,789 \mathrm{a}$ & $0,787 \mathrm{~b}$ & $0,525 \mathrm{c}$ & $0,299 \mathrm{~b}$ \\
t3 & $0,668 \mathrm{a}$ & $0,804 \mathrm{a}$ & $0,828 \mathrm{a}$ & $0,786 \mathrm{~b}$ & $0,814 \mathrm{a}$ & $0,800 \mathrm{~b}$ & $0,822 \mathrm{a}$ & $0,804 \mathrm{a}$ & $0,794 \mathrm{a}$ & $0,798 \mathrm{~b}$ & $0,505 \mathrm{c}$ & $0,279 \mathrm{a}$ \\
t4 & $0,660 \mathrm{a}$ & $0,805 \mathrm{a}$ & $0,831 \mathrm{a}$ & $0,793 \mathrm{~b}$ & $0,821 \mathrm{a}$ & $0,804 \mathrm{~b}$ & $0,830 \mathrm{~b}$ & $0,809 \mathrm{a}$ & $0,817 \mathrm{~b}$ & $0,796 \mathrm{~b}$ & $0,517 \mathrm{c}$ & $0,284 \mathrm{~b}$ \\
t5 & $0,680 \mathrm{a}$ & $0,812 \mathrm{a}$ & $0,831 \mathrm{a}$ & $0,787 \mathrm{~b}$ & $0,827 \mathrm{a}$ & $0,800 \mathrm{~b}$ & $0,830 \mathrm{~b}$ & $0,807 \mathrm{a}$ & $0,806 \mathrm{~b}$ & $0,795 \mathrm{~b}$ & $0,494 \mathrm{c}$ & $0,273 \mathrm{a}$ \\
t6 & $0,684 \mathrm{a}$ & $0,808 \mathrm{a}$ & $0,826 \mathrm{a}$ & $0,776 \mathrm{a}$ & $0,816 \mathrm{a}$ & $0,794 \mathrm{a}$ & $0,818 \mathrm{a}$ & $0,799 \mathrm{a}$ & $0,788 \mathrm{a}$ & $0,776 \mathrm{a}$ & $0,442 \mathrm{~b}$ & $0,272 \mathrm{a}$ \\
\hline
\end{tabular}

* Similar letters in the column indicate statistical equality at $5 \%$ of significance $(P<0.05)$.

Table 6 - Severity of Asian soy rust for witness treatment (Dst1) and control (Dest2) over the time of Experiment 2

\begin{tabular}{|c|c|c|c|c|c|c|c|c|c|}
\hline Treat. & $30 / 01$ & $05 / 02$ & $12 / 02$ & $19 / 02$ & $26 / 02$ & $06 / 03$ & $17 / 03$ & $20 / 03$ & $26 / 03$ \\
\hline Dest2 & $0,000 \mathrm{a}$ & $0,000 a$ & $0,000 \mathrm{a}$ & $0,008 \mathrm{a}$ & $0,000 a$ & $0,000 \mathrm{a}$ & $0,312 \mathrm{a}$ & $2,416 a$ & $8,708 \mathrm{a}$ \\
\hline Dest1 & $0,016 a$ & $0,004 a$ & $0,008 \mathrm{a}$ & $0,008 \mathrm{a}$ & $0,025 a$ & $2,095 \mathrm{a}$ & $12,13 b$ & $44,16 b$ & $51,66 \mathrm{~b}$ \\
\hline
\end{tabular}



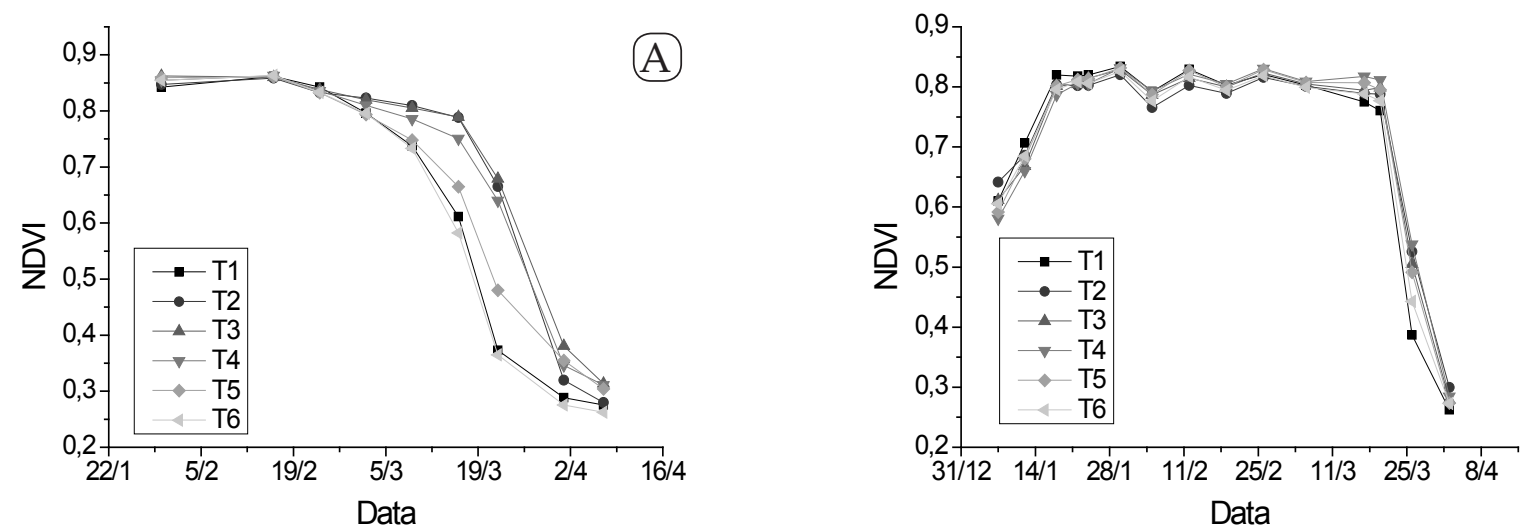

Figure 2 - Normalized difference vegetation index in treatments with different gradients of Asian soy rust ( $T 1, \mathrm{~T} 2, \mathrm{~T} 3, \mathrm{~T} 4, \mathrm{~T} 5$ and T6) over the times of Experiment 1 (A) and Experiment 2 (B).
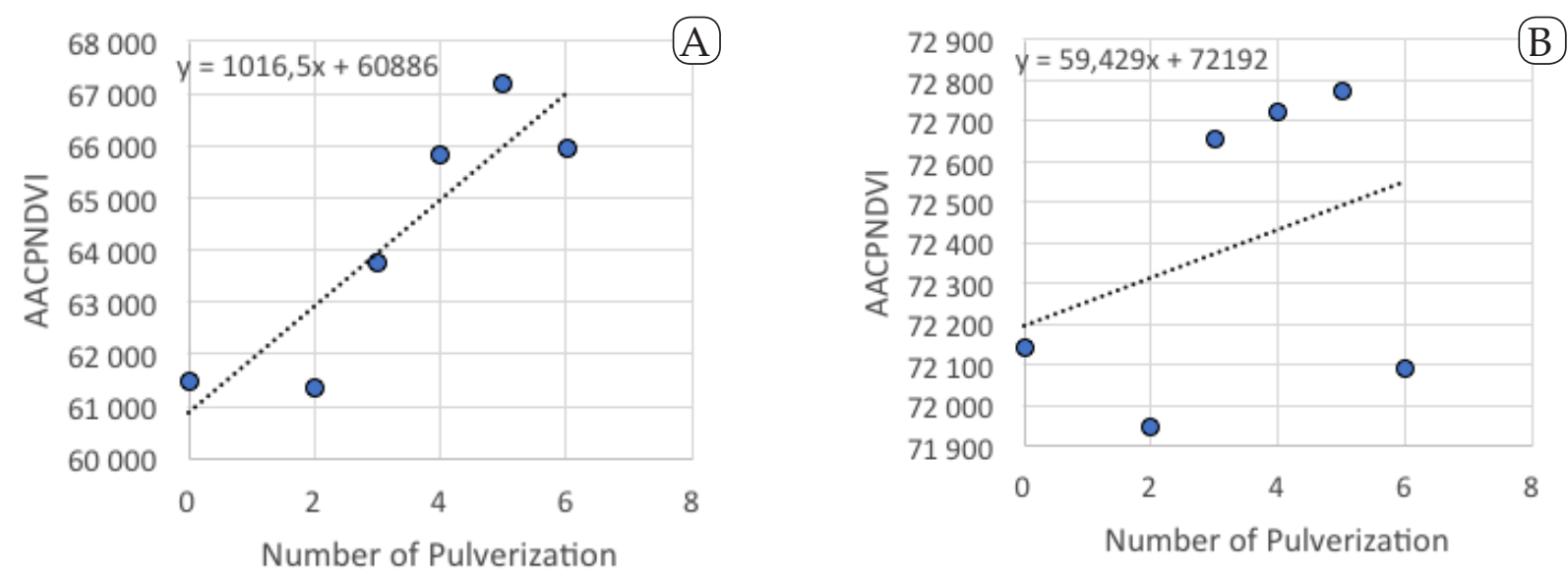

Figure 3 - Area below the NDVI progress curve (AACPNDVI) for Experiment 1 (A) and Experiment 2 (B).

Table 7 - Statistical difference at $5 \%$ significance for the area below the NDVI progress curve (AACPNDVI) for Experiment $1(A)$ and Experiment 2 (B)

\begin{tabular}{cccc}
\hline Trataments & $\begin{array}{c}\text { Number of } \\
\text { Pulverization }\end{array}$ & Experiment 1 & Experiment 2 \\
\hline T1 & 0 & $61.365 \mathrm{~b}$ & $71.947 \mathrm{a}$ \\
T2 & 6 & $61.500 \mathrm{a}$ & $72.145 \mathrm{a}$ \\
T3 & 5 & $63.785 \mathrm{a}$ & $72.657 \mathrm{a}$ \\
T4 & 4 & $65.832 \mathrm{a}$ & $72.725 \mathrm{a}$ \\
T5 & 3 & $65.972 \mathrm{~b}$ & $72.090 \mathrm{a}$ \\
T6 & 2 & $67.192 \mathrm{~b}$ & $72.777 \mathrm{a}$ \\
\hline
\end{tabular}

Even with numerical variations, there were no statistical differences, using the Scott-Knott test at $5 \%$ of significance, between the treatments, in the variable height of the plant, number of pods per plant and number of grains per pod in Experiments 1 and 2 (Table 8).

For the total mass in $\mathrm{kg} \cdot \mathrm{ha}^{-1}$, in Experiment 1 there was a statistical difference between Treatments T1 and T2 when compared to treatments T1, T5 and T6. The control treatment presented a productivity $45.58 \%$ superior to the witness treatment. In Experiment 2 the control treatment presented 
Table 8 - Statistical difference at $5 \%$ of significance in the variables: height of the plant, number of pods per plant, number of grains per pod and mass of 1.000 grains between treatments with different gradients of Asian soy rust

\begin{tabular}{|c|c|c|c|c|c|c|c|}
\hline Experiment & Treatment & Height of plant & Number of pods & $\begin{array}{c}\text { Number of grains } \\
\text { per pod }\end{array}$ & Productivity & \multicolumn{2}{|c|}{ Mass of 1000 grains } \\
\hline \multirow{6}{*}{1} & T1 & 79,05 a & 31,37 a & 1,690 a & $872.50 \quad$ a & $83,84 \pm 20,14$ & $\mathrm{a}$ \\
\hline & $\mathrm{T} 2$ & 82,58 a & 40,75 a & 1,940 a & $1603.19 \mathrm{~b}$ & $107,24 \pm 5,78$ & $\mathrm{~b}$ \\
\hline & T3 & 92,60 a & $48,00 \mathrm{a}$ & 1,948 a & $1467.91 \mathrm{~b}$ & $104,34 \pm 25,14$ & $\mathrm{~b}$ \\
\hline & $\mathrm{T} 4$ & 87,45 a & 34,87 a & 1,947 a & $1576.87 \mathrm{~b}$ & $119,15 \pm 14,96$ & $\mathrm{~b}$ \\
\hline & T5 & 77,75 a & 35,83 a & 2,597 a & 1103.89 a & $92,56 \pm 18,99$ & $\mathrm{a}$ \\
\hline & T6 & 80,40 a & 23,77 a & 1,899 a & 740.69 a & $80,34 \pm 5,50$ & $\mathrm{a}$ \\
\hline \multirow{6}{*}{2} & T1 & 74,10 a & $45,85 \mathrm{a}$ & 2,385 a & 2715,27 a & $162,20 \pm 2,50$ & $\mathrm{a}$ \\
\hline & $\mathrm{T} 2$ & 68,02 a & 39,37 a & 2,355 a & 2717,59 a & $183,72 \pm 9,55$ & $\mathrm{c}$ \\
\hline & $\mathrm{T} 3$ & 70,07 a & $43,90 \mathrm{a}$ & 2,545 a & 2560,18 a & $168,64 \pm 10,50$ & $\mathrm{~b}$ \\
\hline & $\mathrm{T} 4$ & 74,25 a & 41,80 a & 2,546 a & 2615,74 a & $164,99 \pm 8,49$ & $\mathrm{~b}$ \\
\hline & $\mathrm{T} 5$ & $73,70 \mathrm{a}$ & $52,05 \mathrm{a}$ & 2,381 a & 2416,66 a & $171,92 \pm 10,79$ & $\mathrm{~b}$ \\
\hline & T6 & 71,07 a & 45,07 a & 2,520 a & 2481,48 a & $168,83 \pm 8,41$ & $\mathrm{~b}$ \\
\hline
\end{tabular}

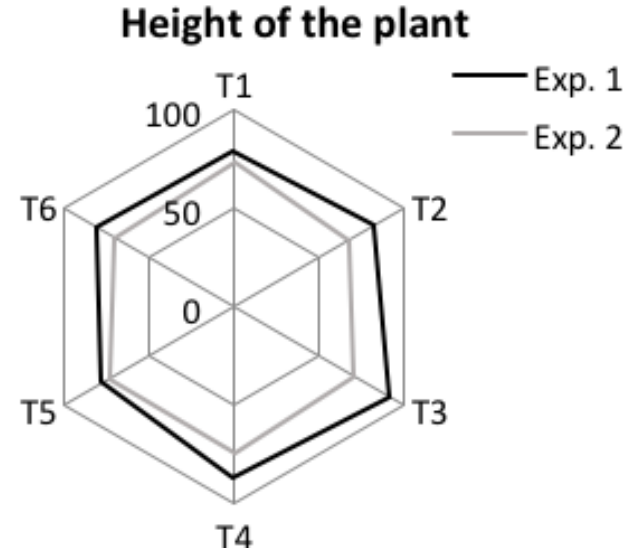

\section{Number of grains per pod}

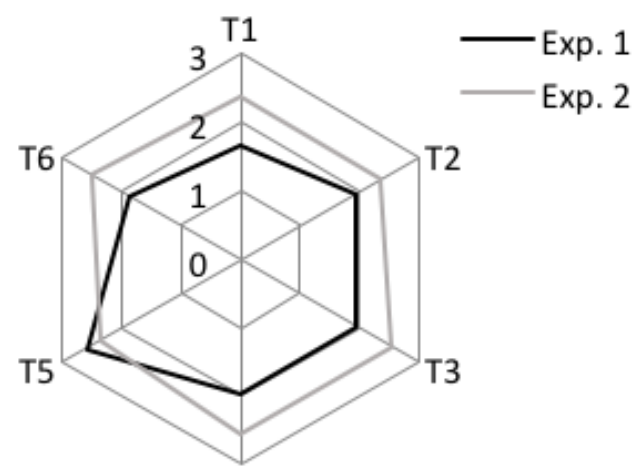

T4
Number of pods per plant

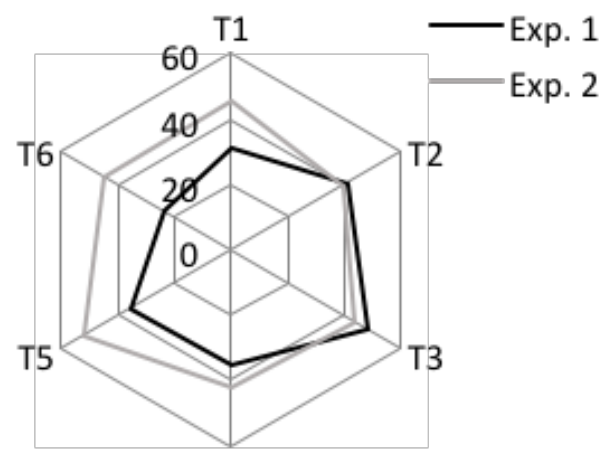

T4

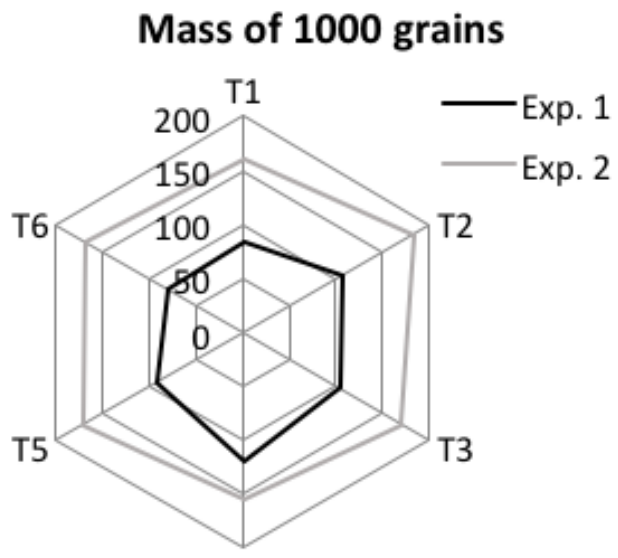

T4

Figure 4 - Height of the plant, number of pods per plant, number of grains per pod and mass of 1.000 grains between treatments with different gradients of Asian soy rust (T1, T2, T3, T4, T5 and T6) of Experiment 1 (Exp. 1) and Experiment 2 (Exp. 2). 
practically the same productivity, that is, a difference of $0.9 \%$. Hikishima et al. (2010) obtained differences of productivity between the control and witness treatments of $26.2 \%, 28,5 \%, 45,2 \%$ e $69,8 \%$.

When analyzing the mass of 1.000 grains in Experiment 1, utilizing the Scott-Knott test at 5\% of significance, a better yield in treatments T2, T3 and $\mathrm{T} 4$ is observed in comparison with treatments $\mathrm{T} 1, \mathrm{~T} 5$ and T6, coinciding with the first difference found in NDVI. The witness treatment presented a result $21.83 \%$ lower when compared with the control treatment.

In Experiment 2, however, the best result was found in treatment T2. Treatments T3, T4, Tt and T6 presented results lower than T2 and higher

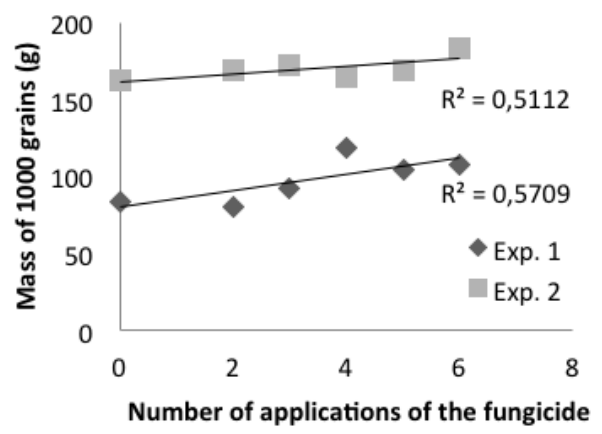

Figure 5 - Ratio of the mass of 1.000 grains with the number of applications of the fungicide in Experiments 1 and 2 . than T1, which, since it was the witness treatment, presented the worst result, that is, $11.72 \%$ lower than the result of the control treatment. The results of statistical differences of the mass of 1.000 grains are not identical to the statistical differences of NDVI, but present a strong representativeness trend. The behavior of the data of Experiments 1 and 2, regarding productivity, may be seen in Figure 4.

The analysis of the mass of 1.000 grains by the number of applications of the fungicide shows a trend to mass in accordance with the number of applications of the defensive (Figure 5) both for Experiment $1(\mathrm{R} 2=57.09)$ and for Experiment 2 $\left(\mathrm{R}^{2}=51.12\right)$.

\section{CONCLUSIONS}

One concludes that NDVI is an item to be taken into consideration for the decision making about the best moment of application of fungicide in the culture of soy for the control of Asian rust. For a more trustworthy result there is the need to increase the frequency of NDVI readings or even to develop a static system with the taking of constant data between the control and witness parcels.

The greatest number of fungicide application is a preventive action for the control of Asian soybean rust and the NDVI presents regular results for the estimation of productivity for the culture of soy.

\section{REFERENCES}

Ali, A.M.; Thind, H.S.; Sharma, S. \& Singh, V. (2014) - Prediction of dry direct-seeded rice yields using chlorophyll meter, leaf color chart and GreenSeeker optical sensor in northwestern India. Field Crops Research, vol. 161, p. 11-15. https://doi.org/10.1016/j.fcr.2014.03.001

Bergamin Filho, A.; Lopes, D.B.; Amorin, L.; Godoy, C.V. \& Berger, R.D. (1995) - Avaliação de danos causados por doenças de plantas. Revisão Anual de Patologia de Plantas, vol. 3, p. 133-184.

Campbell, C.L. \& Madden, L.V. (1990) - Introduction to plant disease epidemiology. New York NY. John Wiley \& Sons.

Carmona, M.; Sautua, F.; Perelman, S.; Gally, M. \& Reis, E.M. (2015) - Development and validation of a fungicide scoring system for management of late season soybean diseases in Argentina. Crop Protection, vol. 70, p. 83-91. https://doi.org/10.1016/j.cropro.2015.01.019

Chang, D.; Zhang, J.; Zhu, L.; Ge, S.-H.; Li, P.-Y. \& Liu, G.-S.(2014) - Delineation of management zones using an active canopy sensor for tobacco field. Computers and Electronics in Agriculture, vol. 109, p. 172-178. https://doi.org/10.1016/j.compag.2014.09.019 
Deb, D.; Engel, B.A.; Harbor, J.; Hahn, L.; Lim, K.J. \& Zhai, T. (2010) - Investigating potential water quality impacts of fungicides used to combat soybean rust in Indiana. Water, Air, and Soil Pollution, vol. 207, n. 1-4, p. 273-288. https://doi.org/10.1007/s11270-009-0135-4

Dorighello, D.V.; Bettiol, W.; Maia, N.B. \& Leite, R.V.B.C. (2015) - Controlling Asian soybean rust (Phakopsora pachyrhizi) with Bacillus spp. and coffee oil. Crop Protection, vol.67, p. 59-65. https://doi.org/10.1016/j. cropro.2014.09.017

Fioreze, S.L.; Pivetta, L.G.; Fano, A.; Machado, F.R. \& Guimarães, V.F. (2011) - Comportamento de genótipos de soja submetido a déficit hídrico intenso em casa de vegetação. Revista Ceres, vol. 58, n. 3, p. 342-349. http://dx.doi.org/10.1590/S0034-737X2011000300015

Furtado, G.Q.; Alves, S.A.M.; Carneiro, L.C.; Godoy, C.V. \& Massola Júnior, N.S. (2009) - Influência do estádio fenológico e da idade dos trifólios de soja na infecção de Phakopsora pachyrhizi. Tropical Plant Pathology, vol. 34, n. 2, p. 118-122. http://dx.doi.org/10.1590/S1982-56762009000200007

Godoy, C.V.; Flausino, A.M.; Santos, L.C.M. \& Del Ponte, E.M. (2009) - Eficiência do controle da ferrugem asiática da soja em função do momento de aplicação sob condições de epidemia em Londrina, PR. Tropical Plant Pathology, vol. 34, n. 1, p. 56-61.

Godoy, C.V.; Koga, L.J. \& Canteri, M.G. (2006) - Diagrammatic scale for assessment of soybean rust severity. Fitopatologia Brasileira, vol. 31, n. 1, p. 63-68. http://dx.doi.org/10.1590/S0100-41582006000100011

Gregorutti, V.C.; Caviglia, O.P. \& Saluso, A. (2012) - Defoliation affects soybean yield depending on time and level of light interception reduction. Australian Journal of Crop Science, vol. 6, n. 7, p. 1166-1171.

Guan, J. \& Nutter Jr., F.W. (2002) - Relationships between defoliation, dry weight, percentage reflectance, leaf-to-stem ratio, and green leaf area index in the Alfalfa Leaf Spot Pathosystem. Crop Science, vol. 42, n. 4, p. 1264-1273. https://doi.org/10.2135/cropsci2002.1264

Hikishima, M.; Canteri, M.G.; Godoy, C.V.; Koga, L.J. \& Silva, A.J. (2010) - Quantificação de danos e relações entre severidade, medidas de refletância e produtividade no patossistema ferrugem asiática da soja. Tropical Plant Pathology, vol. 35, n. 2, p. 96-103. http://dx.doi.org/10.1590/S1982-56762010000200004

Koga, L.J.; Canteri, M.G. \& Godoy, C.V. (2007) - Relação entre medidas de refletância e área foliar sadia, severidade da ferrugem asiática e produtividade da cultura da soja. Semina: Ciências Agrárias, vol. 28, n. 4, p. 571-580.

Martins, J.A.S. \& Juliatti, F.C. (2014) - Genetic control of partial resistance to Asian soybean rust. Acta Scientiarum. Agronomy, vol. 36, n. 1, p. 11-17. http://dx.doi.org/10.4025/actasciagron.v36i1.16919

Michels, R.N.; Canteri, M.G.; Fonseca, I.C. de B.; Silva, M.A. de A. \& França, J.A. de (2015) - Estimation of optimal size of plots for experiments with radiometer in beans. African Journal of Biotechnology, vol. 14, n. 30, p. 2361-2366. http://dx.doi.org/10.5897/AJB2014.13984

Michels, R.N.; Bonafé, E.G.; Figueiredo, L.; Suzuki, R.M.; Tonin, L.D.; Montanher, P.F. \& Aguiar e Silva, M.A. (2016) - Effects of different numbers of fungicide application on the proximate composition of soybean. Journal of the Brazilian Chemical Society, vol. 27, n. 10, p. 1727-1735. http://dx.doi.org/10.5935/0103-5053.20160053

Thompson, N.M.; Epplin, F.M.; Edwards, J.T. \& Hunger, R.M. (2014) - Economics of foliar fungicides for hard red winter wheat in the USA southern Great Plains. Crop Protection, vol. 59, p. 1-6. https://doi.org/10.1016/j. cropro.2014.01.009

Yao, H.; Huang, Y.; Hruska, Z.; Thomson, S.J. \& Reddy, K.N. (2012) - Using vegetation index and modified derivative for early detection of soybean plant injury from glyphosate. Computers and Electronics in Agriculture, vol. 89, p. 145-157. https://doi.org/10.1016/j.compag.2012.09.001

Yao, X.; Yao, X.; Jia, W.; Tian, Y.; Ni, J.; Cao, W. \& Zhu, Y. (2013) - Comparison and intercalibration of vegetation indices from different sensors for monitoring above-ground plant nitrogen uptake in Winter wheat. Sensor, vol. 1, n. 3, p. 3109-3130. https://doi.org/10.3390/s130303109 